\title{
Concept for a new approach to project management in the activities of public servants ${ }^{1}$
}

\author{
Natalia F. Altukhova \\ Associate Professor, Head of Department of Business Informatics \\ Financial University under the Government of the Russian Federation \\ Address: 38, Scherbakovskaya Street, Moscow, 105187, Russian Federation \\ E-mail: nfaltuhova@fa.ru

\section{Elena V. Vasileva} \\ Professor, Department of Business Informatics \\ Financial University under the Government of the Russian Federation \\ Address: 38, Scherbakovskaya Street, Moscow, 105187, Russian Federation \\ E-mail: evvasileva@fa.ru
}

\section{Boris B. Slavin}

Scientific Advisor, Faculty of Applied Mathematics and Information Technology

Professor, Department of Business Informatics

Financial University under the Government of the Russian Federation

Address: 38, Scherbakovskaya Street, Moscow, 105187, Russian Federation

E-mail: bbslavin@fa.ru

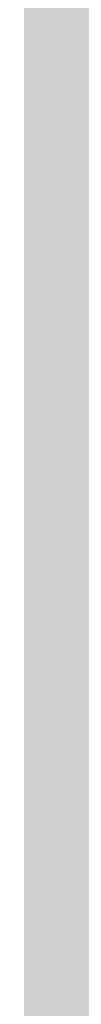

\begin{abstract}
This article presents the results of research into the possibility of adapting flexible methods of project management to the organization of activities of public servants of the Russian Federation and recommendations on combined approaches. The objectives of this research: to identify special aspects of project management in the public service and to evaluate the possibilities for adapting flexible methods of project management to the organization of activities of Russian public servants.

The activities of the public service are becoming increasingly innovative and intelligent and, as a consequence, less predictable. These days the public authorities are not only customers in relation to third organizations, but they themselves act as the direct executors of projects in the elaboration of development programs and legislative initiatives in the framework of executingorders of the President, Government and the higher state authorities. In these circumstances, management principles of the PMBOK and similar standards, which are strictly formalized and require clear planning of processes, no longer work. When the problems are large-scale, technologies are known, and the resources are defined, classical design techniques work flawlessly. But when any innovative goals are set, there may be high risk of exceeding budget funds and time; therefore in this case it is necessary to consider the feasibility of applying Agile-like technologies.

Possibilities for the combination of tough methods (in terms of responsibility and formalization) and flexible methods (in terms of goal-setting and continuity) of project management in the civil service were investigated using analysis of business processes and based on the results of a survey of the public servants participating in the implementation of certain tasks with respect to execution of public functions. It is noted that in contrast to the business-oriented organizations the government authorities are characterized by a significantly reduced motivation to informal leadership and undeveloped self-organization and selfmanagement. This fact imposes restrictions on the processes of implementing approaches of flexible
\end{abstract}

${ }^{1}$ This article was prepared based on the results of research carried with the support of government funds by the State Order of the University of Finance for the year of 2016 "Analysis of the best international practices of information support to realization of public functions. Development of proposals on improvement of information support to activities of civil public servants", state registration number AAAA-A16-116070610054-7 
project management in the activities of public servants, but it does not mean it is impossible to formulate and use them. Based on the results of the study we carried out, we determined principles of flexible project management in the civil service, the knowledge of which can be useful both for the public servants and businesses working with government agencies.

Key words: public servant, public administration, administrative reform, civil service efficiency, project management, new public management, business process.

Citation: Altukhova N.F., Vasileva E.V., Slavin B.B. (2016) Concept for a new approach to project management in the activities of public servants. Business Informatics, no. 4 (38), pp. 60-69.

DOI: 10.17323/1998-0663.2016.4.60.69.

\section{Introduction}

A mong the specific problems of the Russian system of performing public functions, we note the complexity and non-transparency of the processes, redundancy of documents, fuzzy distribution structure and duplication of responsibilities. The problem of interaction between the employees of civil services remains one of the most important. Meanwhile, the statistics show that the number of public servants is continuously increasing. Among other factors, during the period from 1999 to 2013, the number of employees of the state civil and municipal services of the Russian Federation increased 1.6 times [1].

In accordance with the data of the Russian Federal Service of State Statistics [1], the number of employees in government bodies, local self-government authorities and election commissions of municipal structures of the Russian Federation at the end of 2015 came to $2,176,400$ that is 1.87 times more than their number in 2000. The number of employees in the federal government bodies in 2015 came to $1,434,100$, and this is 2.75 times more than in the year of 2000. In 2015, 2,619,000 employees served in the government bodies of the constituent units of the Russian Federation, which is 1.35 times more than in 2000 .

A significant increase in the number of staff of the public administration means there is a need to establish a sustainable cooperation at various organizational levels, effective document management in the subdivisions, reduction of time spent (including time for paperwork) by eliminating low-productivity activities, pointless discussions, etc.

At the heart of the reform of public administration, many countries use the principles of new public management, or administration (NPM) [2, 3]. They are based on the conditions of transparency of public services, restructuring their work in accordance with mar- ket principles, including economic competition between them and with private organizations, material interest of employees in the economic returns from their actions, implementation of ideas of project management in the public administration with the goal of improving its efficiency and reducing expenditures. However, application of the project approach in the public sphere in the Russian Federation during the execution of some tasks has its own distinctive features and limitations.

\section{Assessment of the current situation in the field of project management of the civil service in Russia}

In the civil service, project technologies are usually considered in terms of the implementation of the classical PMBOK methodology (http://www.pmi.ru/). If we talk about the experience of implementing project approaches in the civil service, it is possible to give examples of reorganization and establishment of project offices in the regional government authorities (the Perm Territory, the Belgorod Region, and others). There has been established a Council for the implementation of project management in the federal bodies of the executive branch and the government authorities of the constituent units of the Russian Federation. For the third year in a row, we see the contest "Project Olympus" in the context of implementation of project management in the public sector (http://pmolimp.ru/). In the Tomsk Region, a large-scale project called"INOTomsk'2020"has been introduced to coordinate the government authorities, universities, large-scale businesses and public corporations based on the project approach. There are being established project offices at the level of the Federation constituent units and municipal structures. However, their number is limited to pilot testing of this approach: the results of the monitoring of project management in the bodies of the executive branch and companies with state participation in the year 2013 through project of- 
fices or comparable was found to be $38.5 \%$ of federal bodies of the executive branch and in $31.2 \%$ of the bodies of executive branch of Russian Federation constituent units [4].

At the moment, PMBOK is considered the most developed project management technology. The PMBOK body of rules focuses on the need for careful planning of project activities prior to starting their implementation. Such aspects as who is to participate in the project, how long the project is to last and how much money is required for its implementation are strictly formalized. The risks are assessed and measures to minimize them are taken. All project management procedures are preplanned over time. However, the universality and the large number of documents which describe specific situations make this standard very complicated, including for the understanding by those project participants (in this case by public servants) who do not have any special project training. Therefore, adaptation of this standard for a specific project and the specifics of the organization immediately and completely (and not on the individual chapters, which makes no sense) must be carried out by those who have never faced a problem of project management.As a result, the authors of many research investigations into Russian experience of the implementation of the PMBOK principles in the civil service point out the continuing disregard for the unification of presentation of project materials ("some of them are grouped in the integrated system of electronic document management... in the folders of corresponding functional-target blocks, and some - in the folders of individual public authorities" [5]), the continuing problems of duplication of functions of managers and participants in the project activities ("a new project office is being formed, but there is a ministry that is already solving similar tasks" [6]), as well as the complexity of adapting the principles of project management in the public authorities during evaluation of activity results and formation of the final or intermediate parameters of project performance.

In practice, the majority of public authorities supporting project management tasks use the simplest tools, among which are leading MS Word and MS Excel $(87.5 \%)$. At the same time, $7.7 \%$ of federal bodies of the executive branch and $18.8 \%$ of bodies of the executive branch of Russian Federation constituent units use MS Project [4] for scheduling. The general problem of interaction within the ministries consists in the persisting functional principle of its organization, in which it is easier to control to communicate. The main reason for the low rates of adaptation of project technologies in the civil service is the unpreparedness and lack of understanding by the public authorities than themselves of the benefits of project methodology. Such matters as distribution of rights and responsibilities in terms of interaction with the employees of various functional units of the organization, other administrative entities and bodies of other levels of the administrative authorities, use of outsourcing also by implementing organizations, are usually ignored. The formalization of the work of the public service during organization of project offices or project teams eventually becomes an uncontrollable and complicated process.

Modern trends in the development of the economy and society make public service activities more and more innovative and intelligent and, consequently, less predictable. Nowadays public authorities not only assign tasks to other organizations, but also act themselves as performers of projects in the elaboration of development programs and legislative initiatives. Where problems are complicated and large-scale, planning, of course, is necessary, and the application of classical project methods is justified. If there are high risks of exceeding the budgets and time limits, then the PMBOK standard, strictly formalized, providing clear planning of processes and actively introduced today in the civil service of the Russian Federation, ceases to work. In these circumstances, it is necessary to consider the feasibility of Agile-like technologies. Sometimes one should consider the possibility of combining tough methods (in terms of responsibility and formalization) and flexible methods (in terms of goal-setting and continuity) of project management. Meanwhile, nothing prevents breaking down a large-scale project so that some individual tasks could be implemented by an Agileteam. A flexible approach will make it possible to eliminate problem areas in the project management under the conditions of public service, and to consider the instability of the organizational structure, the need for regular meetings, as well as the unwillingness of the team to keep documentation in high demand in the preservation of the project information for analysis and optimization of the company activities.

\section{Analysis of conditions \\ of informational support of project activities of public servants in Russian organizations}

In the course of the research assessing the state of informational support to performance of public functions, the authors conducted a survey of public servants and employees of subordinated institutions, including administrative boards and the State-Financed Entity "Zhilischnik" of the districts of Moscow and the Moscow Region, the prefecture of one of the districts of Moscow, the Department of Information Technologies 
in the field of the state and municipal financial management and informational support of the budgeting process of the RF Ministry of Finance, as well as some other state organizations. In total, within the framework of our investigation 260 public servants were surveyed. We analyzed various versions of mutual work for solving common tasks, goal-achieving monitoring and team management. We determined the number of projects in which, as a rule, the employees participate at the same time, the volume of urgent and non-urgent tasks to be solved. Wealso considered problems of exceeding working time during the project execution, as well as the terms of automation of administrative processes.

The interview results have confirmed the selected common problems, including the presence of those projects that do not comply with deadlines. The average duration of the delay of the government projects in $33.85 \%$ of the cases was insignificant (up to $1-3$ days), but in $4.6 \%$ of the cases the civil service employees revealed delays for periods of up to one month.

In $11 \%$ of the cases, there was revealed a failure of short-term projects (with duration of up to one week), while such projects could be extended for a period of up to 3 days, and up to six months. The failed projects are characterized by overtime work of the employees. The results of our analysis of the questionnaires show that for the accomplishment of tasks in the projects that were extended for an insignificant period (from 3 days to 1 month), public servants in half of the cases worked after working hours at least once a week, and in $10 \%$ of the cases - every day. In the projects delayed up to six months, in $16.7 \%$ of the cases the civil service employees had to stay at work after working hours practically every other day. Moreover, the survey results have shown that the overtime work is noted by all the employees, regardless of the fact whether the project time limits fail or not.

Analysis has shown that the overwhelming number of business processes in organizations are described, but mostly only document flow for the incoming documents is automated: official correspondence with the higher and lower-level authorities, subordinated institutions, complaints of citizens and organizations, correspondence between the departments. Among the list of possible tools for describing and modelling administrative processes, the document flow for the incoming documents was mentioned by the employees of civil services in $38.2 \%$ of the cases. There is partially automated interaction with the Federal Treasury and banks ( $9 \%$ of the whole number of all the selected tools for automatization of business processes), with suppliers of goods, works and services in the process of concluding government contracts (12.7\%), and with multifunctional centers providing public and municipal services (MFC) to provide services to citizens (10.4\%). Apart from that, the respondents have noted the application of project management automation instruments (9\% of the total number of responses). Such processes as internal coordination of drafts of government contracts, personnel management (planning of training, assessment of the effectiveness of activities), maintenance service (repair of equipment, furniture, air conditioners, etc.), innovation management (submission of proposals, assessment, monitoring of implementation) are not automated or automated only partially (Table 1).

Program products for description and modeling of administrative processes used in the organizations

\begin{tabular}{l|c}
\multicolumn{1}{c|}{ Tools } & $\begin{array}{c}\text { Share in the total number } \\
\text { of investigated organizations }\end{array}$ \\
$\begin{array}{l}\text { Document flow for incoming documents (official correspondence with higher and lower-level authorities, } \\
\text { subordinated institutions, complaints of citizens and organizations, correspondence between the departments) }\end{array}$ & $38.2 \%$ \\
\hline Interaction with suppliers of goods, works and services in the process of concluding government contracts & $12.7 \%$ \\
\hline Interaction with the MFC ("My Documents") to provide services to citizens & $10.4 \%$ \\
\hline Interaction with the Federal Treasury and the banks & $9.0 \%$ \\
\hline Project management & $9.0 \%$ \\
\hline Internal coordination of drafts government contracts & $8.8 \%$ \\
\hline Human resources management (planning of training, assessment of performance of activities) & $6.0 \%$ \\
\hline Maintenance service (repair of equipment, furniture, air conditioners, etc.) & $2.8 \%$ \\
\hline Innovation management (submission of proposals, evaluation, monitoring of realization) & $2.4 \%$ \\
\hline Others & $0.8 \%$ \\
\hline
\end{tabular}


As our investigation of the current situation has demonstrated, there is a particularly acute problem the civil service managing knowledge and competences. The results of the survey carriedout have shown that information about a project's progress, as a rule, is not accumulated, and the electronic archive is kept in $45.6 \%$ of the cases. A project background is createdin only $34 \%$ of the cases, and a project folder on the portal is even rarer $(20.16 \%)$. Information about the people involved in the project is stored in electronic form only in $47 \%$ of the cases, and in $30 \%$ it remains on paper-based media. This means that the employees understand the importance of saving intermediate information about the project, but they do not have any adequate tools for their collection, storage and current and future shared use.

Any new knowledge gained by the employees in the process of advanced vocational training and additional training is not transferred to their colleagues. Only $2 \%$ of the interviewed public servants have responded that their professional knowledge is quite enough for their work, while more than $40 \%$ were not sure of this. A majority of respondents (76\%) mentioned competence assessment as an effective tool for assessing the competence of public servants. In their point of view, the most important factors in the selection and promotion of staff to senior positions in the organization are professional and personal qualities, as well as work experience $(60 \%$ and $50.5 \%$, respectively). At the same time, they place a very low value on such factors as authority in the team $(25 \%)$ and personal desire $(23 \%)$. Selection was made for the most strongly sought-for competences, such as general professional $(81.9 \%)$ and regulatory competences $(80 \%)$ and, with a slight difference, competences in the performance and efficiency of work $(72.4 \%)$. The least popular turned out to be a group of competences "change management" (14.3\%), which is not surprising, because the business processes of public authorities are established "from top down", and working documents of the higher levels of administration often have the status of regulatory documents. We also noted the low demand for the group of competencies of self-management and professional growth $(21.9 \%)$, which can be attributed to the shortcomings of the existing competence-based approaches in government institutions.

In general it can be concluded that the Russian system of public administration is in a transitional state from the first (base) level to the second level (repeated practices), in accordance with the assessment model of the maturity level of management processes with the help of the Capability Maturity Model (CMM) meth- odology (http://www.sei.cmu.edu/cmmi/): bringing administrative processes under regulation, defining efficiency indicators, availability of project controlling systems, general project management methodology and project management training programs for public servants. However, the processes are insufficiently organized and there is no understanding by the employees themselves of the worth of control over achievement of the set goals, as well as of the importance of the information formalizing at each stage of implementation of tasks to be solved. As for the scope and completeness of use of electronic means in the activities of public servants and their cross-functional interaction, it is too early to talk about this [7].

\section{Principles for adapting flexible methods of project management to public service activities}

It should be noted that presently there are several project management techniques that have worked well in solving business problems. They can also be considered as a basis for improving the project activities of civil public servants in terms of their performance of public functions, along with the implementation of the classical PMBOK methodology. The activities of public servants are associated primarily with intellectual activity (preparation of orders, instructions, programs, etc.), and they are more like the work of programmers than that of builders or manufacturers. Therefore, we can actively discuss the application of such techniques and concepts such as the Total Quality Management (TQM), the quality management model of informationtechnology services (Information Technology Service Management, ITSM), Lean Manufacturing, and Six Sigma, a method of the "critical chain" for project management (Critical Chain Project Management, CCPM), Goldratt's theory of constraints (Theory of Constraints, TOC), easy or flexible (Agile) ITprojects management methods using principles of SCRUM, KANBAN, as well as the recently popular hybrid approach SCRUMBAN.

In our opinion, the problems of civil service which remain even after the implementation of the PMBOK principles show that it is impossible to limit the approach to reorganization of the public management system using the classical methodology, even if it has proved its worth. It is necessary to take into consideration the fact that during the process of execution of a project associated with implementation of public functions there are changes of the objectives, number and complexity 
Table 2.

Steps for transition to GovAgile methodology

\begin{tabular}{|c|c|c|c|c|}
\hline & $\begin{array}{l}\text { Principles of Agile } \\
\text { Manifesto }[\mathbf{9}, 10]\end{array}$ & $\begin{array}{l}\text { Principles for } \\
\text { projects in general }\end{array}$ & $\begin{array}{l}\text { Distinctive features } \\
\text { of the civil serviee }\end{array}$ & $\begin{array}{l}\text { GovAgile } \\
\text { prineiples }\end{array}$ \\
\hline 1 & $\begin{array}{l}\text { The highest priority is satisfaction of } \\
\text { customer's needs by the regular and early } \\
\text { delivery of valuable software }\end{array}$ & $\begin{array}{l}\text { The customer of the } \\
\text { project results should } \\
\text { receive them regularly } \\
\text { and rapidly }\end{array}$ & $\begin{array}{l}\text { In the civil service the customer } \\
\text { and sponsor is always the linear } \\
\text { head }\end{array}$ & $\begin{array}{l}\text { The project team members should } \\
\text { include those employees who are } \\
\text { linearly subordinate to the project } \\
\text { sponsor andthecustomer }\end{array}$ \\
\hline 2 & $\begin{array}{l}\text { Changing of requirements is welcome even at } \\
\text { the latest stages of development. The Agileuse } \\
\text { processes allow using changes to provide the } \\
\text { customer with a competitive advantage }\end{array}$ & $\begin{array}{l}\text { Do not be afraid to } \\
\text { change the goals } \\
\text { and objectives in the } \\
\text { process }\end{array}$ & $\begin{array}{l}\text { In the civil service, objectives } \\
\text { are often changing, but they } \\
\text { should be controlled }\end{array}$ & $\begin{array}{l}\text { The project objectives may be } \\
\text { changed by the head, but the } \\
\text { changes should be recorded }\end{array}$ \\
\hline 3 & $\begin{array}{l}\text { An operational product should be produced as } \\
\text { often as possible, at intervals of a couple of } \\
\text { weeks to a couple of months }\end{array}$ & $\begin{array}{l}\text { The results should } \\
\text { appear and be updated } \\
\text { frequently }\end{array}$ & $\begin{array}{l}\text { At all the stages, there should be } \\
\text { reporting parameters }\end{array}$ & $\begin{array}{l}\text { The project should be divided into } \\
\text { stages, each of which has a value } \\
\text { for the customer }\end{array}$ \\
\hline 4 & $\begin{array}{l}\text { Throughout the project, the developers and } \\
\text { business representatives must work together } \\
\text { on a daily basis }\end{array}$ & $\begin{array}{l}\text { The team members } \\
\text { and customers should } \\
\text { regularly discuss the } \\
\text { project }\end{array}$ & $\begin{array}{l}\text { In the civil service, there is } \\
\text { a routine practice of regular } \\
\text { reports, usually not more often } \\
\text { than once a week }\end{array}$ & $\begin{array}{l}\text { The manager must receive reports } \\
\text { about the project on a weekly } \\
\text { basis }\end{array}$ \\
\hline 5 & $\begin{array}{l}\text { The project should be elaborated by motivated } \\
\text { professionals. To accomplish the work, create } \\
\text { for them appropriate conditions, provide } \\
\text { support and fully trust them }\end{array}$ & $\begin{array}{l}\text { The team members } \\
\text { should be motivated } \\
\text { and have the appropri- } \\
\text { ate competences }\end{array}$ & $\begin{array}{l}\text { The team members should be } \\
\text { motivated and have the appropri- } \\
\text { ate competences }\end{array}$ & $\begin{array}{l}\text { The team members should be } \\
\text { motivated and be selected in ac- } \\
\text { cordance with their competences }\end{array}$ \\
\hline 6 & $\begin{array}{l}\text { Direct communication is the most practical } \\
\text { and efficient way to exchange information } \\
\text { both with the team itself and within the team }\end{array}$ & $\begin{array}{l}\text { Personal communica- } \\
\text { tion of team members } \\
\text { is obligatory }\end{array}$ & $\begin{array}{l}\text { Regular meetings of team } \\
\text { members are obligatory }\end{array}$ & $\begin{array}{l}\text { The team members should meet } \\
\text { each other in person at least twice } \\
\text { a week }\end{array}$ \\
\hline 7 & $\begin{array}{l}\text { The operational product is the main indicator } \\
\text { of progress }\end{array}$ & $\begin{array}{l}\text { Everything must be } \\
\text { subordinated to the } \\
\text { results }\end{array}$ & $\begin{array}{l}\text { For the civil service control is of } \\
\text { great importance }\end{array}$ & $\begin{array}{l}\text { Stages of the project and the value } \\
\text { of their results should coincide } \\
\text { with measurable parameters }\end{array}$ \\
\hline 8 & $\begin{array}{l}\text { The investors, developers, and users should } \\
\text { be provided with a possibility to maintain a } \\
\text { constant rhythm. Agile helps to establish such } \\
\text { a sustainable development process }\end{array}$ & $\begin{array}{l}\text { Constant rhythm of the } \\
\text { project management is } \\
\text { obligatory }\end{array}$ & $\begin{array}{l}\text { Regularity of reports dictates } \\
\text { the rhythm of work }\end{array}$ & $\begin{array}{l}\text { Stages of the project should have } \\
\text { approximately the same duration } \\
\text { and to be short (no more than one } \\
\text { quarter) }\end{array}$ \\
\hline 9 & $\begin{array}{l}\text { Continuous attention to technical perfec- } \\
\text { tion and quality of the project development } \\
\text { improves flexibility of the project }\end{array}$ & $\begin{array}{l}\text { Continuous techni- } \\
\text { cal improvement is } \\
\text { obligatory }\end{array}$ & $\begin{array}{l}\text { Continuous technical } \\
\text { improvement is obligatory }\end{array}$ & $\begin{array}{l}\text { Use of innovations in the project } \\
\text { should be encouraged }\end{array}$ \\
\hline 10 & $\begin{array}{l}\text { Simplicity (the art of minimizing unnecessary } \\
\text { work) is needed urgently }\end{array}$ & $\begin{array}{l}\text { Search for simple } \\
\text { solutions }\end{array}$ & $\begin{array}{l}\text { It will require a lot of efforts from } \\
\text { the public servants; they are not } \\
\text { looking for simple solutions }\end{array}$ & $\begin{array}{l}\text { The solutions should be simple } \\
\text { and elegant }\end{array}$ \\
\hline 11 & $\begin{array}{l}\text { Self-organizing teams give rise to the best } \\
\text { requirements, architectural and technical } \\
\text { solutions }\end{array}$ & $\begin{array}{l}\text { Self-organization is } \\
\text { obligatory }\end{array}$ & $\begin{array}{l}\text { It will require a lot of efforts from } \\
\text { the public servants; they are not } \\
\text { used to initiative }\end{array}$ & $\begin{array}{l}\text { It is necessary to motivate initia- } \\
\text { tive and self-organization }\end{array}$ \\
\hline 12 & $\begin{array}{l}\text { The team must systematically analyze the } \\
\text { possible ways to improve efficiency and to } \\
\text { adjust their work style }\end{array}$ & $\begin{array}{l}\text { Improvements should } \\
\text { be continuous }\end{array}$ & $\begin{array}{l}\text { Improvements should be } \\
\text { continuous }\end{array}$ & $\begin{array}{l}\text { It is necessary to make the project } \\
\text { approach be process-relevant and } \\
\text { complywith ISO } 9001\end{array}$ \\
\hline
\end{tabular}

of the tasks, and priorities. In these circumstances, the principles of management should be replaced with the new ones. Different tasks require different approaches, sometimes in conditions of their combinations based on the specific character of sub-tasks. Different conditions of project implementation also make it necessary to apply different tools. In cases where the problems are large- scale, the technologies are known and the resources are defined, the classical project techniques work flawlessly. But when innovative objectives are set, and high risks of exceeding the limits of budgets and time take place, it is necessary to consider the feasibility of applying flexible technologies (in combination with tough technologies or separately). 
In addition, the participation of public servants in projects should match their competencies. Some employees work better using tough technologies, while others work better using flexible technologies, and still others should be generally used in the processes only involving them in fulfillment of single orders - not difficult ones, but, nevertheless, of top priority. Therefore, the authors have formulated the necessity for developing new principles, taking into consideration both the possibilities of flexible project management and rigorous requirements of responsibility on the part of the civil service. These principles include the best practices of application of PMBOK management principles and Agile methodologies for flexible management of the project team of the civil service under conditions of maintaining rigorous requirements on responsibility and formalization of processes.

Flexible methodology focuses on the use of interactive development, dynamic formation of requirements and ensuring their implementation resulting from the continuous interaction within the self-organizing working groups, consisting of experts in various fields [8]. The principles of the Agile methodology [9, 10] are as follows: to pay attention to communication within the team, thus reducing the number of official written documents; to continuously discuss any emerging problemsof the solution being developed and to be prepared for its complete change regardless of the initially intended plan. Just this fact has recently drawn the attention of experts in project management to Agile not only in the field of software development, but also when conducting projects in business and organizations. This makes the given technology of management interesting for implementation in civil service projects. From the flexible methodology of development, SCRUM [11], for the civil service there are valuable principles of cooperation and discussion of all the changes. Thus, the project team could effectively discuss what they have done for a certain period, which errors have occurred on the way, how they could possibly be corrected and what is planned next. But the SCRUM, as an individually functioning methodology, cannot provide maximum performance of the project team, and therefore it requires additional tools and review of current problems for the purpose of time release. Today in those projects that provide for the creation of a software product by small groups and within a limited time it has been decided to combine flexible methodologies SCRUM and KANBAN [12]. For such an integrated approach, there has even appeared a new term: SCRUMBAN [13]. However, in contrast to the appli- cation of flexible technologies in business, civil service projects should be based not only on the international experience of implementation, but to take into consideration national peculiarities.

The study of distinctive features of project management in the civil service and assessment of the possibility of adapting the flexible methods of project management to the organization of work of public servants in the Russian Federation have allowed the authors to formulate GovAgile principles - the principles of flexible project management in the civil service. Table 2 shows the steps of sequential transition from Agile in software development to Agile in business and Agile in the civil service.

In general, in the field of project management it is necessary to apply a subject-oriented approach which takes into consideration special abilities of the employee. The project approach is to be customer-oriented; it should comprise the tools of continuous improvement, and the employees should be motivated to achieve it. The framework of the project approach requires expanding the standards of activities of public servants with due consideration of flexible methods of project management in cases where the result has an innovative character. Moreover, the time management system should set provisions for implementation of the priority assignments.

\section{Conclusion}

The task of organizing effective interaction between civil service employees is very important. Continuing challenges of the public service show that it is impossible to limit the approach to reorganization of the public management system using only the PMBOK. During the process of implementing the project approach and management by objectives for the realization of public functions by civil public servants, one must also apply and adapt the principles of various management methodologies, including flexible methodologies.

In consequence of the research we carried out, we revealed certain problem areas of activities of civil public servants during the implementation of public functions. This is, above all, a low level of automation of business processes. As a rule, there are systems of document flow automation and means of interaction with the suppliers and financial organizations. In the process of performing public functions, some projects fail; work of the staff after the working hours is commonly observed. Not withstanding the fact that the employees recognize the importance of maintaining the project information, it 
usually remains only on paper-based media. Apart from that, there remains the problem of knowledge management in the civil service. The Russian system of public administration is characterized by availability of a project design work monitoring system and a project management training program for public servants. However, there remains the undecided question about the readiness of the federal and regional authorities themselves for internal reforms, and the readiness of public servants to change perceptions about their personal responsibility for the implementation of projects.

The steps of sequential transition from Agile in development of information systems and business to application of the GovAgile methodology in the civil service are formulated. Possibilities of combining tough and flexible project management methods in the civil service have been investigated based on analysis of business processes and in accordance with the results of a survey of public servants involved in the implementation of certain tasks relating to the execution of public functions. We noted that, in contrast to the business-oriented organizations, motivation of informal leadership in the government authorities is significantly reduced, and self-organization and self-management are not developed.

Analysis of the results of interviewing public servants has revealed the specific character of the civil service which should be kept in mind when implementing Agile in project management. For example, the project customer and sponsor in Agile wording is always the linear head, the prevailing function is controlling, and initiative itself is suppressed. All these factors impose restrictions on the processes of implementing the flexible project management approaches in the activities of public servants, but they do not mean it is impossible to formulate and use them.

\section{References}

1. Federal State Statistics Service (2016) State, public organizations. Available at: http://www.gks.ru/wps/wcm/connect/rosstat_main/rosstat/ $\mathrm{ru} /$ statistics/state (accessed 01 August 2016) (in Russian).

2. Sivintseva O.V. (2013) Instrumenty NPM v institutsional'noy srede sovremennogo Kitaya [NPM instruments in the institutional environment of modern China]. ArsAdministrandi, no. 4, pp. 89-101 (inRussian)

3. Obolonsky A.V. (2002) Byurokratiya dlya XXI veka? Modeli gosudarstvennoy sluzhby - Rossiya, SShA, Angliya, Avstraliya [Bureaucracy for the 21 st century? Models of public service - Russia, USA, England, Australia]. Moscow: Delo (inRussian).

4. Zolochevskaya E.Yu., Krivosheeva T.D. (2014) Funktsional'naya kharakteristika rossiyskoy sistemy upravleniya gosudarstvennymi proektami [Functional characteristic of Russian public project management system]. Management Issues, no. 6, pp. 42-49 (in Russian).

5. Krasilnikov D.G., Yakimova M.N. (2011) Standart PMBOK i proektnoeupravlenie v organakh gosudarstvennoy vlasti Permskogo kraya: priblizhenie $\mathrm{k}$ idealu[PMBOK standard and project management in public authorities of Perm Region: an approximation to the ideal]. ArsAdministrandi, no. 3, pp. 44-54 (in Russian).

6. Vodopyanov V. (2010) Povtornyy prem'ernyy pokaz [Repeatedpremiere]. Commersant.ru, 16 November 2010. Available at: http://www.kommersant.ru/doc/1540468/print (accessed 12 November 2016) (in Russian).

7. Ivanov V.V., Korobova A.N. (2016) Gosudarstvennoe i munitsipal'noe upravlenie s ispol'zovaniem informatsionnykh tekhnologiy [Public and municipal management using information technologies]. Moscow: INFRA-M (inRussian).

8. Rechkalov V. (2015) Agile i Kriticheskaya tsep' [Agile and Critical path]. TOCPEOPLE. Community of theory of constraints. Available at: http://tocpeople.com/2015/11/agile-i-kriticheskaya-cep/ (accessed 10 March 2016) (in Russian).

9. Beck K., Beedle M., van Bennekum A., et al. (2001) Manifesto for Agile software development. Available at: http://www.agilemanifesto.org (accessed 16 May 2016).

10. Real ITSM (2015) 10 aspektov Agile Development ot Gartner [10 aspects of Agile Development from Gartner]. Available at: http://www.realitsm.ru/2015/07/10-aspektov-agile-development-ot-gartner/ (accessed 16 May 2016) (in Russian).

11. Sutherland J. (2016) SCRUM. Revolyutsionnyy metod upravleniya proektami [SCRUM. A revolutionary method of project management]. Moscow: Mann, Ivanov and Ferber (in Russian).

12. Japan Management Association (2014) Kanban i tochno vovremya na Toyota: Menedzhment nachinaetsya na rabochem meste [Kanban and Just-in-Time at Toyota: Management begins at the workplace]. Moscow: Alpina Publisher (in Russian).

13. Sibiriks (2016) Scrumban. Rukovodstvo pol'zovatelya [Scrumban. Users' manual]. Available at: http://scrumban.helpdesk.sibirix.ru/docs/ scrumban/scrumban-manual.pdf(accessed 11 November 2016) (in Russian). 


\title{
Концепция нового подхода к управлению проектами в деятельности государственных служащих²
}

\author{
Н.Ф. Алтухова \\ кандидат экономических наук, заведующая кафедрой бизнес-информатики \\ Финансовый университет при Правительстве РФ \\ Адрес: 105187, г. Москва, ул. Щербаковская, д. 38 \\ E-mail:nfaltuhova@fa.ru
}

\section{Е.В. Васильева}

доктор экономических наук, профессор кафедры бизнес-информатики Финансовый университет при Правительстве РФ Адрес: 105187, г. Москва, ул. Щербаковская, д. 38 E-mail: evvasileva@fa.ru

\section{Б.Б. Славин}

кандидат физико-математических наук научный руководитель факультета прикладной математики и информационных технологий профессор кафедры бизнес-информатики Финансовый университет при Правительстве РФ Адрес: 105187, г. Москва, ул. Щербаковская, д. 38

E-mail: bbslavin@fa.ru

\section{Аннотация}

В статье представлены результаты исследования возможности адаптации гибких методов проектного управления к организации работы государственных служащих РФ, даны рекомендации по сочетанию различных подходов. Цели исследования - выявить особенности проектного управления в государственной службе и оценить возможности адаптации гибких методов проектного управления к организации работы государственных служащих России.

Деятельность государственной службы становится все более инновационной и интеллектуальной и, как следствие, менее предсказуемой. Органы государственной власти сегодня выступают не только в роли заказчиковпо отношению к сторонним организациям, но и сами являются непосредственными исполнителями проектов в области разработки программ развития и законодательных инициатив, в рамках выполнения поручений Президента, Правительства и вышестоящих инстанций. В этих условиях принципы управления РМВОКи аналогичных стандартов, которые строго формализованы и предполагают четкое планирование процессов, перестают работать. Там, где задачи являются масштабными, технологии известны, а ресурсы определены, классические проектные методики действуют безупречно. Если же ставятся новаторские цели, то возникают высокие риски превышения бюджетов и времени, поэтому в этом случае необходимо рассматривать целесообразность применения Agile-подобных технологий.

Возможности сочетания жестких (с точки зрения ответственности и формализации) и гибких (с точки зрения целеполагания и непрерывности) методов управления проектами в госслужбе исследовались на основе анализа бизнес-процессов и по результатам опроса государственных служащих, участвовавших в реализации тех или иных задач по исполнению государственных функций. Отмечено, что, в отличие от бизнес-ориентированных организаций, в органах государственной власти существенно снижена мотивация к неформальному лидерству, не развиты самоорганизация и самоменеджмент. Это накладывает ограничения на процессы внедрения подходов гибкого проектного управления в деятельности госслужащих, но не означает невозможность их формулирования и использования. На основе результатов проведенного исследования определены принципы гибкого проектного управления в госслужбе, знание которых может быть полезным как для самих госслужащих, так и для бизнеса, работающего с государственными структурами.

Ключевые слова: государственный служащий, государственное управление, административная реформа, эффективность государственной службы, управление проектами, новый государственный менеджмент, бизнес-процесс.

Цитирование: Altukhova N.F., Vasileva E.V., Slavin B.B. Concept for a new approach to project management in the activities of public servants// Business Informatics. 2016. No. 4 (38). P. 60-69. DOI: 10.17323/1998-0663.2016.4.60.69.

\footnotetext{
2 Статья подготовлена по результатам исследований, выполненных за счет бюджетных средств по Государственному заданию Финансового университета 2016 года «Анализ лучших зарубежных практик информационного обеспечения реализации государственных функций. Разработка практик информационного обеспечения реализации государственных функций. Разработка гражданских служащих», номер государственной регистрации АААА-А16-116070610054-7.
} 


\section{Литература}

1. Федеральная служба государственной статистики России. Государство, общественные организации [Электронный ресурс]: http://www.gks.ru/wps/wcm/connect/rosstat_main/rosstat/ru/statistics/state (дата обращения 01.08.2016).

2. Сивинцева О.В. Инструменты NPM в институциональной среде современного Китая // ArsAdministrandi. 2013. № 4. C. 89-101.

3. Оболонский А.В. Бюрократия для XXI века? Модели государственной службы - Россия, США, Англия, Австралия. М.: Дело, 2002. 165 c.

4. Золочевская Е.Ю., Кривошеева Т.Д. Функциональная характеристика российской системы управления государственными проектами // Вопросы управления. 2014. № 6. С. 42-49.

5. Красильников Д.Г., Якимова М.Н. Стандарт РМВОК и проектное управление в органах государственной власти Пермского края: приближение к идеалу // ArsAdministrandi. 2011. № 3. С. 44-54.

6. Водопьянов В. Повторный премьерный показ // Коммерсант.ru, 16.11.2010 [Электронный pecypc]: http://www.kommersant.ru/ doc/1540468/print (дата обращения: 12.11.2016).

7. Иванов В.В., Коробова А.Н. Государственное и муниципальное управление с использованием информационных технологий. М.: ИНФРА-М, 2016. $382 \mathrm{c}$.

8. Речкалов B. Agile и Критическая цепь // TOCPEOPLE. Сообщество теории ограничений [Электронный ресурс]: http://tocpeople. com/2015/11/agile-i-kriticheskaya-cep/ (дата обращения: 10.03.2016).

9. Manifesto for Agile software development / K. Beck [et al.].[Электронный ресурс]: http://www.agilemanifesto.org (дата обращения: 16.05.2016).

10. 10 аспектов AgileDevelopment от Гартнер // Real ITSM, 21.07.2015 [Электронный pecypc]: http://www.realitsm.ru/2015/07/ 10-aspektov-agile-development-ot-gartner/ (дата обращения: 16.05.2016).

11. Сазерленд Дж. SCRUM. Революционный метод управления проектами. М.: Манн, Иванов и Фербер, 2016.288 с.

12. Канбан и точно вовремя на Тоуота: Менеджмент начинается на рабочем месте. М.: Альпина Паблишер, 2014.214 с.

13. Scrumban. Руководство пользователя [Электронный pecypc]: http://scrumban.helpdesk.sibirix.ru/docs/scrumban/scrumban-manual. pdf (дата обращения: 11.11.2016). 